THURSDAY, AUGUST I4, I884

\section{THE REPORT ON TECHNICAL INSTRUCTION}

THE Report of the Royal Commissioners on Technical Instruction is now before the public. These two volumes, together with the short interim Report on Apprenticeship Schools in France, which was issued two years ago, extend over a wide range of matter. The Commissioners' account of their travels abroad and at home is narrated in vol. i., which concludes with their various recommendations. Vol. ii. contains a Report on Agricultural Education, by Mr. Jenkins, and another on Technical Education in America, by Mr. Wm. Mather. In the remaining volumes will be found a Report by Mr. Wardle on Silk Industries, and a scheme by Prof. Sullivan for Technical Education in Ireland, and a variety of Statistics and Programmes are also promised.

The immense mass of detail thus gathered together in this voluminous and interesting blue-book renders it a matter of some difficulty to give anything like an adequate review of the labours of the Commission. In the present article we shall confine our attention to that part of the Report which deals with technical schools in foreign countries, reserving for a second notice that part of the Report which relates to Great Britain.

The Commissioners preface their account of Continental Technical Instruction with some concise introductory notices of the general conditions of Primary and Secondary Education in various nations. Their remarks on the gradation of schools, on the use of school museums, and on the prominence given to drawing are worthy of attention. After these notices the Commissioners deal with artisans' evening technical schools, artisans' apprenticeship schools, intermediate technical schools for foremen, trade and professional schools for women, and the higher technical instruction for employers and managers. Concerning the first of these matters the Commissioners remark on the value of the numerous continuation-schools (Fortbildungschulen) which exist in nearly all towns of Germany and Switzerland. It appears that in Bavaria, Baden, and elsewhere, pupils leaving the primary schools at the age of 13 are compelled by law to continue their studies in the evening schools until the age of 16 : a truly wise rule, calculated to sustain the benefits of school training at a period when such training is too often pre. maturely cut short. It also appears that although in no country abroad is there any organisation for systematic evening instruction at all comparable to that under the control of our Science and Art Department, the teaching, at least in many foreign towns, is conducted by professors of higher standing than, and of superior attainments to, the ordinary English "science-teacher" who, it must be confessed, is too often sadly deficient in training. On the subject of artisan apprenticeship schools the Commissioners do not add much to the information given two years ago in their preliminary report, so far as France is concerned; but, in relation to some of the German schools, as, for example, the clock-making and wood-carving schools at Furtwangen and other districts of the Black Forest, there is much interesting information. In Wurtemburg there are no such schools, as the VOL. XXX.-No. 772 authorities prefer to attempt to give sound education by means of evening and Sunday schools, without interfering with the conditions of daily labour.

In regard to Intermediate Technical Schools for foremen and others much is being done abroad, both in the special departments of weaving, mining, and industrial art, and in more general schools. In France particularly this is the case. The great schools of this type at Lyons, Rheims, and Paris are practically unique. There is nothing approaching them in this country except perhaps the Allan Glen's Institution in Glasgow. These schools and the secondary technical schools of Germany are claborately described. The Higher Trade Institute of Chemnitz, and the four "Industrie-Schulen" of Munich, Augsburg, Nüremberg, and Kaiserslautern are of this class, intermediate between the Real-Schulen and the Polytechnics. No classics are taught in these schools. Throughout Austria, Germany, France, and Holland there are also special schools for mining and for the building trades. The Commissioners devote many pages to the weaving schools, which, like those of Chemnitz, Crefeld, and Mulhouse, are to be found doing work of utmost importance to the continental industries. The spirit with which municipalities and manufacturers support these schools is truly remarkable. Employers are constantly looking out for students who have attended the technical classes. The manufacturers feel it imperative to extend their work in order that in troublous times they may have more than one string to their bow. Thus in Crefeld, where silk goods are the staple manufacture, much attention is given in the weaving school to the weaving of jute, wool, and cotton. The people cheerfully tax themselves to pay for efficient management. They recognise that the day has gone by when money can be made without effort: "to exist they must move on." Heavily taxed as the German people are by the burden of enormous civil and military expenditure, they yet believe that it is cheapest in the long run to educate the "human machine" to the highest pitch of perfection.

It is, however, with the higher technical instruction, with the great Polytechnic colleges of Germany, and with the École Centrale and École Polytechnique of Paris that the interest of the Commissioners' Report culminates. The German Polytechnics form a group of institutions of which the type is absolutely wanting in this country. These institutions, though in many respects resembling the German universities, differ absolutely from them, not merely in being technical and practical, but in having fixed curricula of study, and regular systems of examination. The eleven schools of this type (eight of which are in Germany proper, one at Zürich, one at Delft, one at Moscow) have been built at a cost of not less than three millions sterling, and are maintained at an annual cost of over $200,000 l$. This amounts to a State expenditure of about Iool. per annum for each student in attendance. This may be contrasted with the case of the two leading English Universities of Cambridge and Oxford. These and their colleges are believed to have a total annual income from endowments of $500,000 l$., and as there are about 5000 men in total attending the two Universities, this also is at the rate of Iool. per annum per student. There is, however, room in the Polytechnic for three times the number of students 
actually in attendance. A few figures respecting some of these schools will show how these institutions stand in public opinion. The Munich Technical High School cost $\mathrm{r}_{57}$, oool., the apparatus alone being worth $36,000 l$, and the annual expenses amounting to $20,000 \%$. The Zuirich Polytechnic spends $20,000 l$. annually, $\mathrm{I} 3,800 \mathrm{l}$. being derived from Federal taxes, and $3794 l$. only from fees. There are forty-five professors on the lecturing staff. 50,000l. have just been spent on laboratory extension. The Stuttgart Polytechnic has a State subvention of I2,00ol, that of Dresden 12,200l. The Hanover Polytechnic cost 350,000l.; its collection of models (chiefly engineering), $36, \infty 00 \%$, and $1250 l$. is spent every year in adding to the collection. Some idea of the preparation made for teaching engineering students may be gathered from the fact that there are stated to be in this one school no fewer than 673 tables for drawing. The Berlin Polytechnic, now nearly completed, has cost 450,00ol.; that of Moscow 496,oool. The chemical laboratory of the Polytechnic of Aachen alone cost 45,000l. The Bernouillianum of Berne cost that little town more than $\mathrm{r} l$. per inhabitant! At such a price do our neighbours provide for the higher technical training. In France, too, the technical schools are maintained at great cost. In the École Polytechnique, salaries alone amount to $22,000 l$. per annum. A new addition to the laboratories is costing $96,000 l$. All this is found by the Government. On the other hand the École Centrale, which spends $17,836 \%$. per annum, is self-supporting, the fees being very high.

From this enormous expenditure of money on Higher Technical Education, tangible results cannot but accrue. Many such are mentioned in the pages of the Commissioners' Report. They adduce examples of improvements in machinery which are the result to a large extent of students' training. They point out how in Continental chemical works and dye works there is a thoroughly trained chemist at the head of each separate department. They indorse the opinion of. Prof. von Helmholtz as to the absolute economy of employing as heads of departments persons conversant with the theory of their work, and able by virtue of their scientific knowledge to anticipate results and to make quantitative calculations. They remark that in physics, as also in chemistry, the knowledge of the principles of the science and of the methods of research is the more important part of the equipment of the technical student. They ascribe the general diffusion of high scientific knowledge in Germany to the multiplication of the Polytechnics, and to the small cost of a higher or University education. Amongst the opinions, which they quote, of authoritative speakers, there is one of particular appositeness from the mouth of Prof. Quincke. He holds that it is an error to suppose that any Polytechnic course of instruction can by itself teach a student to erect an engine, work a blast-furnace, or manufacture sulphuric acid: he holds that lectures and laboratory work are obviously insufficient to prepare the student for carrying on work where actual practical experience is needed; but that, in contradistinction, the object of the Polytechnic School is to facilitate the transition from pure science to practice. The functions of the Polytechnic have probably never before been so well defined. It may be an open question what kind of training is the best to qualify a man to be manager of an in- dustrial concern. But there can be no question whatever of the consensus of opinion on the Continent as to the value of the Polytechnic training. It may not, nay, cannot, supplant the experience of the workshop: but it gives something that no amount of mere workshop experience can give-something which, were it suitably introduced into industrial Britain, would supply the greatest industrial want of our time.

\section{BRITISH MINING}

British Mining, a Treatise on the History, Discovery, Practical Development, and Future Prospects of Metalliferous Mines in the United Kingdom. By Robert Hunt, F.R.S. 4to. Pp. xx. 944, 23 I Woodcuts and 2 Folding Plates. (London : Crosby Lockwood and Co., r884.)

THE title shows that the author's object is to describe the past and present condition of British metal mines, and to venture some prophecies as to their future. It requires a bold heart to attempt a work of this kind; but, as explained in the preface, Mr. Hunt's long connection with mines and his official position as Keeper of Mining Records have given him excellent opportunities for gathering information.

The work is divided into four books. Book I. gives a long historical sketch of British metal mining from the time of the Phœnicians downwards. With reference to St. Michael's Mount being their trading station, the author indorses the old Cornish tradition and disagrees (p. 845) with Prof. Rhys, who has suggested that the Isle of 'Thanet was the Iktis of Diodorus. From detached memoirs and reports much information has been collated concerning mining work carried on by the Romans for lead, iron, copper, and gold.

In Chapter III., upon mining to the eighteenth century, Mr. Hunt fixes very exactly the date of the introduction of gunpowder for blasting in Cornish mines. Chapters IV., V., and VI., relating to the mining of tin, copper, lead, silver, iron, and zinc to the end of the eighteenth century, are full of valuable facts, and both here and in Chapter III. we notice many interesting statements concerning the special privileges of miners and the charters granted to them.

Book II., occupying one-third of the volume, is devoted to the formation of metalliferous deposits. The rocks and mineral veins of the principal mining districts are described, and long quotations are made from sundry writers. Mr. Hunt then sets forth the hypotheses of the best-known authors concerning the origin of lodes, and very wisely does not bind himself to any particular theory; he admits that mineral veins have been formed by deposition in fissures from lateral infiltration, from surface-water carrying down soluble salts they have dissolved out in their passage, and lastly, from ascending mineral springs. He further considers that many of the conditions observed are due to electro-chemical influences.

In the last chapter of this book the author brings forward instances of remarkable tin, lead, and copper mines in Cornwall, Wales, Ireland, and the North of England.

Book III., which is of the same length as the preceding one, is a treatise on practical mining. Rock-boring by machinery very properly comes in for a large share of attention, but some other departments of mining are 